\title{
Modulation of Oxidative Stress Responses by Vitamin E, or Vitamin A plus Vitamin C Treatment in Human Retinal Pigment Epithelial Cells
}

\author{
Jinggang Yin ${ }^{*}$, Christina S. Winborn ${ }^{1}$, Fridtjof Thomas ${ }^{2}$, Quynh T. Tran², John C. Lang3, \\ Edward Chaum ${ }^{1,4}$ \\ ${ }^{1}$ From the Departments of Ophthalmology, University of Tennessee Health Science Center, Memphis, USA \\ ${ }^{2}$ Preventive Medicine, University of Tennessee Health Science Center, Memphis, USA \\ ${ }^{3}$ Department of Chemistry and Biochemistry, University of Texas at Arlington, Arlington, USA \\ ${ }^{4}$ Anatomy and Neurobiology, University of Tennessee Health Science Center, Memphis, USA \\ Email:echaum@uthsc.edu
}

Received 27 August 2015; accepted 22 November 2015; published 25 November 2015

Copyright (C) 2015 by authors and Scientific Research Publishing Inc.

This work is licensed under the Creative Commons Attribution International License (CC BY). http://creativecommons.org/licenses/by/4.0/

(c) (i) Open Access

\section{Abstract}

The purpose of this study was to characterize the potential of vitamins to protect the retinal pigment epithelium (RPE) from oxidative stress (OS). We have previously shown that OS induces the expression of AP1 transcription factors (FOSB, CFOS and ATF3), but is modulated by pretreatment with vitamin $C(200 \mu \mathrm{M})$. We propose that OS-induced AP1 expression can be used as a biomarker of OS to test the efficacy of vitamins to limit the impact of OS in the RPE. Here we examined the efficacy of vitamin $E$ or combined vitamin A plus vitamin C to modulate OS-induced AP1 expression in the RPE. We pretreated human ARPE-19 cells with vitamin E $(0-7.5 \mu \mathrm{M})$ or with combined vitamin A (10 or $15 \mu \mathrm{M})$ plus vitamin C (50 or $100 \mu \mathrm{M})$ for 3 days prior to exposure to $500 \mu \mathrm{M} \mathrm{H}_{2} \mathrm{O}_{2}$ OS for 1 - $4 \mathrm{~h}$. AP1 expression was assessed using qRT-PCR. Pretreatment with $\geq 2.5 \mu \mathrm{M}$ vitamin $\mathrm{E}$ significantly decreased OS-induced AP1 expression at 1 - $4 \mathrm{~h}$ OS, compared to controls. Lower doses of vitamin $E$ were ineffective at modulating OS responses. Pretreatment with $100 \mu \mathrm{M}$ vitamin $\mathrm{C}$ combined with $15 \mu \mathrm{M}$ vitamin A protected RPE cells from OS-induced AP1 expression. There is an additive and potentially protective effect of $100 \mu \mathrm{M}$ vitamin $\mathrm{C}$ and $15 \mu \mathrm{M}$ vitamin $\mathrm{A}$ on FOSB expression at $4 \mathrm{~h}$, and a potentially protective effect of $100 \mu \mathrm{M}$ vitamin $\mathrm{C}$ and $15 \mu \mathrm{M}$ vitamin $\mathrm{A}$ on CFOS expression at $1 \mathrm{~h}$ OS. A protective effect was also seen with $15 \mu \mathrm{M}$ vitamin A pretreatment alone on ATF3 expression. Thus, "sub-therapeutic" levels of multiple vitamins may protect RPE cells better than higher doses of a single vitamin. This OS-induced AP1 expression biomarker

\footnotetext{
*These authors contributed equally to this work.

How to cite this paper: Yin, J.G., Winborn, C.S., Thomas, F., Tran, Q.T., Lang, J.C. and Chaum, E. (2015) Modulation of Oxidative Stress Responses by Vitamin E, or Vitamin A plus Vitamin C Treatment in Human Retinal Pigment Epithelial Cells. Natural Science, 7, 558-570. http://dx.doi.org/10.4236/ns.2015.712056
} 
assay may be useful to identify complex antioxidant formulations as therapeutics for degenerative diseases that are thought to be caused by $0 S$, like age-related macular degeneration.

\title{
Keywords
}

\author{
Vitamin Supplementation, AP1 Transcription Factors, Oxidative Stress, Retinal Pigment \\ Epithelium, Age-Related Macular Degeneration
}

\section{Introduction}

Age-related macular degeneration (AMD) is the most common cause of visual impairment in aging populations in the industrialized world and results from complex interactions between environmental, nutritional and genetic factors. AMD pathology includes degeneration of the retinal pigment epithelium (RPE), the photoreceptors, Bruch's membrane and neural retina. Elevated exposure to oxidative stress (OS) is thought to be a fundamental mechanism of AMD disease pathogenesis [1]-[3]. The RPE in vivo is exposed to chronically high levels of harmful reactive oxygen and nitrogen species (ROS/RNS), which are produced from high rates of mitochondrial respiration, high retinal oxygen content, direct photic damage, digestion of oxidized outer segment membrane lipids and lipofuscin-sensitized photo-oxidation [1]-[4]. This OS can be modulated by endogenous and dietary antioxidants, however if the ROS levels exceed these repair mechanisms, then oxidative damage to proteins, DNA, RNA and organelles can occur. Because limiting ROS accumulation is important for maintaining normal retinal function, and because multivitamin supplementation was shown in the Age-Related Eye Disease Study to reduce the risk of moderate AMD disease progression to advanced AMD [5] [6], current research has focused on identifying dietary and nutritional antioxidants that limit OS in the retina and that may be efficacious for AMD therapy.

Dietary exposure to vitamins A, C, and E plays an important role in neutralizing ROS and maintaining homeostasis in the retina. Vitamin A and its derivatives affect many developmental and differentiation pathways in the cell by modulating gene expression through inhibition of AP1 (activator protein) transcriptional activity and through its antioxidant free radical scavenger properties [7]-[13], all of which make vitamin A supplementation an attractive therapy to limit OS-induced damage for a variety of neurodegenerative disorders, including AMD [14]-[16]. Vitamin C is an essential nutrient that functions as an enzyme co-factor and is the most abundant watersoluble antioxidant in the blood. Vitamin $\mathrm{C}$ is found in the cytoplasm and in cell membranes where it scavenges ROS and protects the cell from free radical-mediated OS induced-cell damage, and also protects cell membranes by recycling vitamin E, thereby preventing lipid peroxidation [17]-[21]. Vitamin E is a major lipid-soluble antioxidant in mammalian membranes and blood and is a chain-breaking antioxidant that can react with peroxyl radicals to inhibit auto-oxidation of polyunsaturated fatty acids and lipoproteins of cell membranes [22]-[26]. Vitamin E plays an important role in ocular homeostasis, and vitamin E deficiency causes retinal degenerative diseases in animal models. Importantly, treatment with these vitamins has been shown to protect various cell types, including RPE cells, from OS-induced cytotoxicity and from OS-induced gene expression and altered activity of transcription factors, including AP1 [27]-[32].

The major AP1 transcription factor family genes include members of the FOS, JUN and ATF subfamilies, and collectively are important regulators of redox status, cellular homeostasis and proliferation. Many extracellular stimuli, including $\mathrm{H}_{2} \mathrm{O}_{2}$ oxidative stress and ultraviolet damage, can activate the diverse signaling pathways that triggers phosphorylation of AP1 proteins, including stress kinases, mitogen-activated protein kinases (MAPK/ ERK) and NFkB pathways [33]-[37]. AP1 proteins play a major role in controlling the cellular responses to extracellular stress by regulating the expression of genes that control cell survival, apoptosis, proliferation and differentiation [36] [38]-[43], and these effects are moderated by different transcriptional activities of the various AP1 dimers [44] [45]. We have previously shown that AP1 genes FOSB, CFOS, and ATF3 are key early molecular responders whose mRNA and protein levels are dose and time dependently activated in RPE cells in response to $\mathrm{H}_{2} \mathrm{O}_{2}$ OS. This OS response can be reduced by pretreating the cells with $200 \mu \mathrm{M}$ vitamin C but is not seen at lower levels of vitamin C supplementation [46] [47]. We have proposed that OS-mediated AP1 expression represents a biomarker for the response of RPE cells to OS and can be used to screen compounds that 
may be efficacious at lowering OS in the RPE.

We are interested in understanding the cellular and molecular mechanisms by which vitamins exerts their protective effects in the RPE, and examining the effective dose ranges for single and combined vitamin treatment in the RPE. This may provide a rationale for the use of multiple vitamin combinations at lower levels as therapy for patients with AMD. The purpose of this study was to examine and quantify the effects of vitamin E pretreatment or combined vitamin A plus vitamin C pretreatment on OS-induced AP1 expression in the RPE, and to determine if combinations of vitamins at "sub-therapeutic" lower doses has an additive or synergistic protective effect against OS in the RPE.

\section{Materials and Methods}

\subsection{Reagents}

Dulbecco's Modified Eagle’s Medium: Nutrient Mixture F-12 (DMEM/F12 as a 1:1 mixture, Invitrogen), fetal bovine serum (FBS, Atlanta Biologicals), L-glutamine (Lonza), penicillin (Lonza), streptomycin (Lonza). trypsin-EDTA, $\mathrm{H}_{2} \mathrm{O}_{2}$ (Sigma Aldrich), REGM media (Lonza), vitamin E ( $\alpha$-Tocopherol, Sigma Aldrich), vitamin A (Sigma Aldrich), vitamin C (Sigma Aldrich), TRI reagent (Sigma Aldrich), dimethyl sulfoxide (DMSO, Sigma Aldrich), Reverse Transcription (RT) system (Promega), 1X SYBR ${ }^{\circledR}$ Green master mix (Applied Biosystems).

\subsection{Cell Culture Conditions, Vitamin Pretreatment, and Oxidative Stress Exposure}

The cell line ARPE-19, a naturally arising, immortal retinal pigment epithelial cell line obtained from the eye of a normal 19 year old male, was obtained from ATCC, and was cultured at $37 \mathrm{C}$ and $5 \% \mathrm{CO}_{2}$ in Dulbecco's Modified Eagle's Medium: Nutrient Mixture F-12 (DMEM/F12) media supplemented with 10\% fetal bovine serum (FBS), $2 \mathrm{mM}$ L-glutamine, and $100 \mathrm{U} / \mathrm{ml}$ penicillin and $100 \mathrm{ug} / \mathrm{ml}$ streptomycin. When cultures reached confluence, as determined visually by brightfield microscopy, cells were detached by incubation with trypsin-EDTA, diluted 1:5 and plated in 6-well dishes for experiments. The formula for DMEM/F12 medium can be found at: http://www.thermofisher.com/us/en/home/technical-resources/media-formulation.54.html.

Confluent cultures of ARPE-19 cells were pretreated with vitamins for 3 days prior to exposure to $500 \mu \mathrm{M}$ $\mathrm{H}_{2} \mathrm{O}_{2} \mathrm{OS}$ as described previously [46]. We selected the dosage and duration of OS exposure based on our prior work with ARPE-19 cells [46]. The concentration of vitamin C was selected based on our previous experiments [47] and the concentrations of vitamin A and E were selected based on a literature search of similar studies. Briefly, cultures were maintained in REGM media (contains 0.5\% serum, EGF, insulin, hydrocortisone and transferrin) for 3 days with vitamin $\mathrm{E}(0,0.5,1,1.5,2.5,5$, or $7.5 \mu \mathrm{M})$ or combined vitamin $\mathrm{A}(10$ or $15 \mu \mathrm{M})$ and $\mathrm{C}(50$ or $100 \mu \mathrm{M})$. To avoid any chemical interaction between vitamins and $\mathrm{H}_{2} \mathrm{O}_{2}$, the media was then replaced with conditioned REGM media (without vitamins) $24 \mathrm{~h}$ prior to OS exposure. APRE-19 cells were exposed to OS for $1-4 \mathrm{~h}$ by addition of fresh $\mathrm{H}_{2} \mathrm{O}_{2}(500 \mu \mathrm{M})$ to the conditioned REGM media. Cultures were either lysed prior to OS exposure $(0 \mathrm{~h})$ or $1 \mathrm{~h}, 4 \mathrm{~h}$ or $8 \mathrm{~h}$ after exposure to OS by addition of TRI reagent to the wells and total cellular RNA was isolated from the cells as recommended by the manufacturer [47] [48]. We generated a vitamin $\mathrm{E}$ that would not precipitate out of solution by dissolving vitamin $\mathrm{E}$ ( $\alpha$-Tocopherol) in dimethyl sulfoxide (DMSO) at a concentration of $3.0 \mathrm{mM}$, which was then serially diluted with FBS to generate $200 \times$ concentrated vitamin E-FBS stock solutions $(100 \mu \mathrm{M}$ to $1500 \mu \mathrm{M})$ [49]. We used these vitamin E-FBS solutions to make REGM media containing 0.5\% FBS, 0 - $7.5 \mu \mathrm{M}$ vitamin $\mathrm{E}$ and $0.05 \%$ DMSO. All procedures were performed under dim red light illumination to minimize the potential influence of light on RPE gene expression.

\subsection{Real-Time qPCR Studies}

Total cellular RNA was isolated from the cells after OS exposure using TRI reagent, and $1.0 \mu \mathrm{g}$ of total RNA was reverse transcribed (RT) to cDNA using random hexamer primers, as described previously [46] [47]. Briefly, real-time qPCR was performed using an ABI PRISM ${ }^{8} 7700$ Sequence Detection System with 1/40 of the cDNA product, $1 \mathrm{X}$ SYBR ${ }^{\circledR}$ Green master mix and $120 \mathrm{nM}$ each primer. The qPCR reaction conditions were $50^{\circ} \mathrm{C}$ for $2 \mathrm{~min}, 95^{\circ} \mathrm{C}$ for $10 \mathrm{~min}$, followed by 40 cycles of $95^{\circ} \mathrm{C}$ for $15 \mathrm{~s}$ and $60^{\circ} \mathrm{C}$ for $1 \mathrm{~min}$. We use Ct and differences in $\mathrm{Ct}(\Delta \mathrm{Ct})$ as measures of gene expression levels (and differences in expression) and maintain these 
scales in the reporting of our results. In RT-PCR, a one unit decrease on the $\Delta \mathrm{Ct}$-scale equates to a two-fold increase in induced expression, and vice versa. Likewise, the first, second, third, etc. additional cycle, Ct, corresponds to a $2^{1}=2$ fold, $2^{2}=4$ fold, $2^{3}=8$-fold decrease in induced gene expression. We use this relationship to translate throughout, e.g., $\Delta \mathrm{Ct}=0.5$ to a $2^{0.5}=1.41$ fold decrease of gene expression. Each reaction was performed in triplicate. Primer sequences included FBJ murine osteosarcoma viral oncogene homolog B (FOSB) [GenBank: NM_006732]: forward, 5'-GTG TGA GCG CTT CTG CAG C- 3', reverse, 5'-CCA ATT CAA CGG CTC GCT T- 3'; CFOS [GenBank: NM_005252.3]: forward, 5'-TGT CTG TGG CTT CCC TTG ATC TGA- 3', reverse, 5'-TGG ATG CTG GGA ACA GGA AGT- 3'; ATF3 [GenBank: NM_001674.3]: forward, 5'-ACG TGT ATT GTC CGG GCT CAG AAT- 3', reverse, 5'-AGG AAG ACA GCT CTC CAA TGG CTT$3^{\prime}$.

\subsection{Statistical Methods}

We collected the data in triplicate samples from three independent experiments and analyzed expression of FOSB, CFOS and ATF3 0 - $8 \mathrm{~h}$ after OS. We normalized each data point relative to those obtained for $0 \mu \mathrm{M}$ vitamin pretreatment at each respective OS time point $(\Delta \mathrm{Ct})$, for each of the three independent experiments. In quantitative RT-PCR, a one unit decrease on the $\Delta \mathrm{Ct}$-scale equates to a two-fold increase in induced transcription and vice versa. We used the computational platforms R (v. 2.15.1) and R-package "multcomp" (v.1.2 - 15) and (v.2.15.1 $\times 64$ ) by Hothorn et al. [50] for statistical analysis of vitamin E and vitamin A plus C data, respectively.

For vitamin E pretreatment, we used statistical methods as described previously [47]. Briefly, we control the family-wise error rate of these tests at $\alpha=0.05$ (Bonferroni method [51]) and used ANOVA to derive confidence intervals for pair-wise comparisons of the gene expression levels associated with the vitamin $\mathrm{E}$ levels 0 8 h OS (8 h data not shown). For each gene, we controlled the 95\% family-wise confidence level for these intervals by adjusting the confidence intervals for the multiple comparisons (21 pair-wise comparisons) using Tukey's method [52]. Point estimates of mean differences in $\Delta \mathrm{Ct}$ values at the various vitamin $\mathrm{E}$ pretreatment levels (vertical scale, Figure 1) are shown as solid circles. Confidence intervals that include the 0 vertical axis correspond to statistically non-significant differences (dotted line, Figure 1).

For combined vitamin A and C pretreatment, we applied essentially a design known as two-factor factorial experiment with both factors, vitamin A and C, tested on respective "low" and "high" levels only, where response was measured relative to specimen that lacked pre-treatments with vitamins. We fit separate linear models for each gene with $\Delta \mathrm{Ct}$ as the dependent outcome variable and the vitamin $\mathrm{A}$ and $\mathrm{C}$ levels as "explanatory" variables on a coded scale from -1 (respective "low level") to +1 (respective "high level") [53]. Our specific research question relates to the statistical model structure as follows: Since we used low concentrations of vitamin $\mathrm{C}$, we included the vitamin $\mathrm{C}$ factor in the models independent of its statistical significance (sub-therapeutic levels of vitamin C). If vitamin A has an additional effect on vitamin C-mediated OS responses in RPE cells in vitro, then we should find the main effect vitamin A parameter to be statistically significant in a model already containing vitamin C. If, in addition, a synergistic effect is present between vitamin C and A pretreatments, then we should find the interaction term between vitamin $A$ and $C$ to be statistically significant.

\section{Results}

\subsection{Vitamin E Pretreatment Modulates OS-Induced AP1 Expression in the RPE}

Because oxidative stress (OS) exposure is considered a key mechanism in AMD disease pathology and because we have shown that $500 \mu \mathrm{M} \mathrm{H}_{2} \mathrm{O}_{2}$ OS time-dependently increases mRNA and protein levels of AP1 transcription factors, we examined the ability of vitamin E treatment to modulate OS-induced AP1 expression in RPE cells in vitro. We exposed ARPE-19 cells to $0-7.5 \mu \mathrm{M}$ vitamin $\mathrm{E}$ for 3 days, incubated cells in vitamin-free conditioned media for $24 \mathrm{~h}$, exposed the cells to $500 \mu \mathrm{M} \mathrm{H} \mathrm{H}_{2} \mathrm{O}_{2}$ OS for $0-4 \mathrm{~h}$, and AP1 expression was quantified 0 - $8 \mathrm{~h}$ after OS exposure using qRT-PCR, as described previously [47]. Consistent with our previous data, exposure of RPE cells to $500 \mu \mathrm{M} \mathrm{H}_{2} \mathrm{O}_{2}$ OS without vitamin pretreatment caused an increase in FOSB and ATF3 expression that was maximal at $4 \mathrm{~h}$ OS and returned to baseline levels within $8 \mathrm{~h}$, and a rapid increase in CFOS expression at $1 \mathrm{~h}$ OS that returned to baseline levels within $4 \mathrm{~h}$ of OS (data not shown). Pretreatment with 2.5 $7.5 \mu \mathrm{M}$ vitamin E significantly decreased OS-induced FOSB expression at $1 \mathrm{~h}$ and $4 \mathrm{~h}$ OS (maximum $\Delta \mathrm{Ct}=1.4$ 

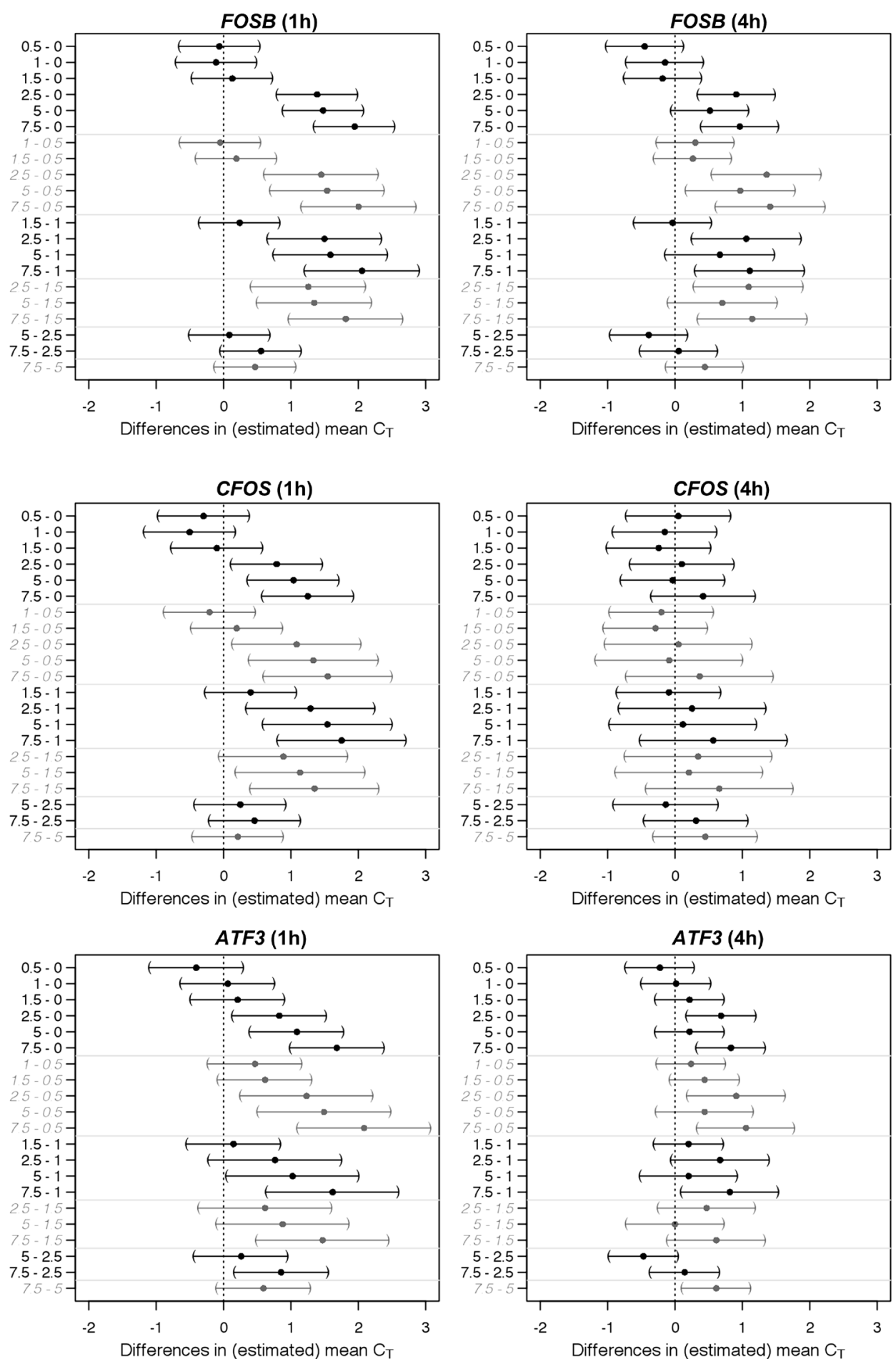

Figure 1. Quantitative assessment of vitamin E pretreatment on AP1 gene expression following OS. The data shows the effect of increasing levels of vitamin E pretreatment on FOSB, CFOS, and ATF3 expression in APRE-19 cells at $1 \mathrm{~h}$ and $4 \mathrm{~h}$ after exposure to $500 \mu \mathrm{M} \mathrm{H}_{2} \mathrm{O}_{2}$ oxidative stress. The displayed intervals have a 95\% family-wise confidence level and are corrected for the 21 discrete pair-wise comparisons using Tukey's method. Point estimates of mean differences in Ct values at the various vitamin E levels (vertical scale) are shown as solid circles. Confidence intervals that include 0 (dotted line) correspond to statistically non-significant differences in mean Ct values. Example of interpretation: FOSB at $1 \mathrm{~h}$ (upper left panel) shows significant differences of 2.5 vs 0 $\mu \mathrm{M}$ - see "2.5 - 0" on vertical axis—, but lack of such difference for 1.5 vs $0 \mu \mathrm{M}$ - see " 1.5 - 0" on vertical axis. 
and 0.68), CFOS expression at $1 \mathrm{~h}$ OS (maximum $\triangle \mathrm{Ct}=0.89$ ), and ATF3 expression at $1 \mathrm{~h}$ and $4 \mathrm{~h}$ OS (maximum $\Delta \mathrm{Ct}=1.19$ and 0.59 ), relative to controls (Table 1). We observed a "threshold" response of vitamin $\mathrm{E}$ on OS-induced AP1 expression in which vitamin E levels less than $2.5 \mu \mathrm{M}$ were ineffective at modulating OS-induced AP1 expression, and vitamin E levels above $2.5 \mu \mathrm{M}$ did not further reduce AP1 expression.

To determine if there is a dose-dependent effect of vitamin E on AP1 expression, we used Tukey's method to display the confidence intervals for pair-wise differences of vitamin E treatment on AP1 expression (Figure 1). Non-significant differences are indicated by values that include the dotted 0 -vertical line, and are seen in response to doses from $0.5 \mu \mathrm{M}-1.5 \mu \mathrm{M}$ vitamin E pretreatment on AP1 expression at $1 \mathrm{~h}$ and $4 \mathrm{~h}$ OS relative to no treatment controls. Significant differences in the mean $\triangle \mathrm{Ct}$ are observed at pretreatment of $2.5-7.5 \mu \mathrm{M}$ vitamin $\mathrm{E}$ for FOSB at $1 \mathrm{~h}$ and $4 \mathrm{~h} \mathrm{OS,CFOS}$ at $1 \mathrm{~h} \mathrm{OS}$ and ATF3 at $1 \mathrm{~h}$ and $4 \mathrm{~h}$ OS when compared to $0.5-1.5$ $\mu \mathrm{M}$ vitamin E pretreatment and no treatment controls (Figure 1). However, no significant differences were observed when comparing responses above $2.5 \mu \mathrm{M}$ vitamin E. Thus, no dose-dependent response was observed. This suggests that the effect of vitamin E on OS-induced AP1 expression depended only on threshold dose of $2.5 \mu \mathrm{M}$ without any dose-dependent response to higher doses of vitamin E. The absence of an evident effect for CFOS at $4 \mathrm{~h}$ OS is due to the fact that OS-induced CFOS expression rapidly returns to baseline within $4 \mathrm{~h}$ OS.

\subsection{Combined Pretreatment with Vitamin A and C Modulates RPE Response to OS}

We have previously shown that $200 \mu \mathrm{M}$ vitamin C reduces OS-induced AP1 expression, while $100 \mu \mathrm{M}$ showed a small but statistically insignificant effect on AP1 expression [47]. To determine if combined treatment with "sub-therapeutic" doses of vitamins would enhance their protective effect, we pretreated ARPE-19 cells with combined vitamin A (10 $\mu \mathrm{M}$ or $15 \mu \mathrm{M})$ plus vitamin C (50 $\mu \mathrm{M}$ or $100 \mu \mathrm{M})$ and exposed the cells to OS as described above. OS-induced FOSB expression was significantly reduced by pretreatment with $100 \mu \mathrm{M}$ vitamin C and $15 \mu \mathrm{M}$ vitamin A at $1 \mathrm{~h}$ OS and at all tested vitamin levels at $4 \mathrm{~h}$ OS (maximum $\Delta \mathrm{Ct}=1.49$ and 2.12, respectively) (Table 2). At $1 \mathrm{~h}$ OS, CFOS expression was significantly reduced by all vitamin pretreatment levels except $100 \mu \mathrm{M}$ vitamin $\mathrm{C}$ plus $10 \mu \mathrm{M}$ vitamin $\mathrm{A}$, and was significantly reduced by all vitamin pretreatment levels at $4 \mathrm{~h}$ OS (maximum $\Delta \mathrm{Ct}=2.3$ and 1.32, respectively) (Table 2). OS-induced ATF3 expression was significantly reduced by pretreatment with $100 \mu \mathrm{M}$ vitamin C and $15 \mu \mathrm{M}$ vitamin A at $1 \mathrm{~h}$ OS and by $50 \mu \mathrm{M}$ vitamin $\mathrm{C}$ and $10 \mu \mathrm{M}$ vitamin $\mathrm{A}$ at $4 \mathrm{~h}$ OS $(\Delta \mathrm{Ct}=1.74$ and 0.56 , respectively) (Table 2$)$.

To understand the nature of the effect of combined vitamin $\mathrm{C}$ and $\mathrm{A}$ pretreatment, we normalized the $\Delta \mathrm{Ct}$ values to $50 \mu \mathrm{M}$ vitamin $\mathrm{C}$ plus $10 \mu \mathrm{M}$ vitamin $\mathrm{A}$, and compared the consequences of increasing vitamin $\mathrm{A}$ or $\mathrm{C}$

Table 1. Effect of Different Concentrations of Vitamin E Pretreatment on OS-induced FOSB, CFOS, and ATF3 Gene Expression.

\begin{tabular}{cccccccc}
\hline & \multicolumn{3}{c}{$1 \mathrm{~h}$ OS } & \multicolumn{3}{c}{$4 \mathrm{~h}$ OS } \\
\hline \multirow{2}{*}{ FOSB } & VitE & $\Delta \mathrm{Ct}$ & $\mathrm{SE}$ & P-Value & $\Delta \mathrm{Ct}$ & $\mathrm{SE}$ & P-Value \\
& $2.5 \mu \mathrm{M}$ & 0.98 & 0.14 & $<0.0001^{*}$ & 0.64 & 0.1 & $<0.0001^{*}$ \\
& $5.0 \mu \mathrm{M}$ & 1.00 & 0.17 & $<0.0001^{*}$ & 0.37 & 0.12 & 0.0072 \\
& $7.5 \mu \mathrm{M}$ & 1.40 & 0.14 & $<0.0001^{*}$ & 0.68 & 0.11 & $<0.0001^{*}$ \\
\hline \multirow{2}{*}{ CFOS } & $2.5 \mu \mathrm{M}$ & 0.56 & 0.15 & 0.0011 & 0.15 & 0.13 & 0.2628 \\
& $5.0 \mu \mathrm{M}$ & 0.73 & 0.16 & $0.0001^{*}$ & 0.33 & 0.19 & 0.0925 \\
& $7.5 \mu \mathrm{M}$ & 0.89 & 0.12 & $<0.0001^{*}$ & 0.37 & 0.12 & 0.0063 \\
\hline \multirow{2}{*}{ ATF3 } & $2.5 \mu \mathrm{M}$ & 0.59 & 0.15 & 0.0012 & 0.48 & 0.13 & 0.0010 \\
& $5.0 \mu \mathrm{M}$ & 0.77 & 0.17 & $0.0003^{*}$ & 0.15 & 0.14 & 0.2921 \\
& $7.5 \mu \mathrm{M}$ & 1.19 & 0.22 & $<0.0001^{*}$ & 0.59 & 0.13 & $0.0002^{*}$ \\
\hline
\end{tabular}

$\Delta \mathrm{Ct}$ are estimated differences between the indicated vitamin $\mathrm{E}$ pretreatment level $(2.5,5$, or $7.5 \mu \mathrm{M})$ minus the 0 $\mu \mathrm{M}$ vitamin E value at 1 and $4 \mathrm{~h}$ OS, respectively, as indicated in the table, fitting a separate linear model for each combination of gene and vitamin E level that incorporates experiment ID as a factor. P-Values: marginal P-values for $\Delta \mathrm{Ct}$ are given (two-sided tests for 0 difference). ${ }^{*}$ Remain statistically significant on family-wise error rate $\alpha=$ 0.05 after Bonferroni correction for the conducted 72 tests (additional VitE levels of 0.5 , 1, and $1.5 \mu \mathrm{M}$ and data from $0 \mathrm{~h}$ and $8 \mathrm{~h}$ not shown in table but were included in testing). 
Table 2. Pretreatment with Vitamin $\mathrm{C}$ and Vitamin A Inhibits $\mathrm{H}_{2} \mathrm{O}_{2}$-Induced Increase in FOSB, CFOS, and ATF3 Gene Expression.

\begin{tabular}{|c|c|c|c|c|c|c|c|c|}
\hline & & & & $1 \mathrm{~h} \mathrm{O}$ & & & $4 \mathrm{~h} \mathrm{OS}$ & \\
\hline & VitC & VitA & $\Delta \mathrm{Ct}$ & SE & P-Value & $\Delta \mathrm{C}_{\mathrm{t}}$ & SE & P-Value \\
\hline \multirow{4}{*}{ FOSB } & \multirow{2}{*}{$50 \mu \mathrm{M}$} & $10 \mu \mathrm{M}$ & 0.68 & 0.34 & 0.0696 & 1.02 & 0.17 & $<0.0001^{*}$ \\
\hline & & $15 \mu \mathrm{M}$ & 0.82 & 0.29 & 0.0122 & 1.21 & 0.19 & $<0.0001^{*}$ \\
\hline & \multirow{2}{*}{$100 \mu \mathrm{M}$} & $10 \mu \mathrm{M}$ & 0.84 & 0.47 & 0.0914 & 1.26 & 0.21 & $<0.0001^{*}$ \\
\hline & & $15 \mu \mathrm{M}$ & 1.49 & 0.32 & $0.0004^{*}$ & 2.12 & 0.4 & $0.0001^{*}$ \\
\hline \multirow{4}{*}{ CFOS } & \multirow{2}{*}{$50 \mu \mathrm{M}$} & $10 \mu \mathrm{M}$ & 1.77 & 0.33 & $0.0001^{*}$ & 1.32 & 0.2 & $<0.0001^{*}$ \\
\hline & & $15 \mu \mathrm{M}$ & 1.63 & 0.33 & $0.0002^{*}$ & 1.16 & 0.13 & $<0.0001^{*}$ \\
\hline & \multirow{2}{*}{$100 \mu \mathrm{M}$} & $10 \mu \mathrm{M}$ & 0.98 & 0.46 & 0.0522 & 1.4 & 0.13 & $<0.0001^{*}$ \\
\hline & & $15 \mu \mathrm{M}$ & 2.3 & 0.34 & $<0.0001^{*}$ & 0.66 & 0.11 & $<0.0001^{*}$ \\
\hline \multirow{4}{*}{ ATF3 } & \multirow{2}{*}{$50 \mu \mathrm{M}$} & $10 \mu \mathrm{M}$ & 0.72 & 0.25 & 0.0123 & 0.56 & 0.11 & $0.0002^{*}$ \\
\hline & & $15 \mu \mathrm{M}$ & 0.93 & 0.25 & 0.0025 & 1.22 & 0.33 & 0.0022 \\
\hline & \multirow{2}{*}{$100 \mu \mathrm{M}$} & $10 \mu \mathrm{M}$ & 0.55 & 0.27 & 0.0613 & 0.25 & 0.17 & 0.1613 \\
\hline & & $15 \mu \mathrm{M}$ & 1.74 & 0.37 & $0.0003^{*}$ & 2.42 & 0.76 & 0.0064 \\
\hline
\end{tabular}

$\Delta \mathrm{Ct}$ are estimated differences: indicated VitC and VitA pretreatment minus $0 \mu \mathrm{M}$ VitC and VitA at $1 \mathrm{~h}$ or $4 \mathrm{~h}$ OS as indicated in the table, fitting a separate linear model for each combination of gene and VitC/VitA-level that incorporates experiment ID as a factor. P-Values: marginal P-values for $\Delta \mathrm{Ct}$ are given (two-sided tests for 0 difference). ${ }^{*}$ Remain statistically significant on family-wise error rate $\alpha=0.05$ after Bonferroni correction for the conducted 48 tests (additional data from $0 \mathrm{~h}$ and $8 \mathrm{~h}$ not shown in table but were included in testing).

levels on AP1 expression. This analysis indicates if there is a protective effect (vitamin pretreatments lower AP1 expression), an additive effect (meaning the decrease in AP1 expression is equal to the sum of the effect of exposure to only vitamin $C$ or only vitamin A), a synergistic effect (meaning the decrease in AP1 expression is greater than the sum of individual treatment with vitamin $\mathrm{C}$ or vitamin A), or an antagonistic effect (meaning combined treatment is less effective than treatment with either vitamin alone). The fitted linear models for each gene with $\Delta \mathrm{Ct}$ as the dependent outcome, as a function of the respective "low" and "high" values for vitamin A and $\mathrm{C}$ (including any possible interactions), resulted in the following findings within the range of administered vitamin A and C levels: For FOSB at $4 \mathrm{~h}$, (time point of maximal OS response transcription) we conclude that there is an additive protective effect of pretreatment with vitamin $\mathrm{A}$ and $\mathrm{C}$ with respect to transcription levels but no evidence for a synergistic effect (no interaction-term in the model). For CFOS at $1 \mathrm{~h}$, (time point of maximal OS response transcription) we conclude that there is a substantial interaction between vitamin $\mathrm{A}$ and $\mathrm{C}$ (statistically, i.e., as related to the transcription level, not necessarily in terms of chemical/biological interaction between these agents) that modulates the effect of each vitamin on AP1 expression levels depending on whether the other vitamin is administered in its respective "low" or "high" dose. A potentially protective effect is only achieved when $100 \mu \mathrm{M}$ vitamin $\mathrm{C}$ are concurrently administered with $15 \mu \mathrm{M}$ vitamin $\mathrm{A}$, and is not observed when a lower dose of either vitamin is delivered. For ATF3 at $4 \mathrm{~h}$, (time point of maximal OS response transcription) we conclude that there is a potentially protective effect of a pretreatment with the higher dose of vitamin A, but no statistically significant change in transcription level could be found when changing vitamin $\mathrm{C}$ from 50 to $100 \mu \mathrm{M}$, at least when 10 or $15 \mu \mathrm{M}$ vitamin A are concurrently administered.

\section{Discussion}

Elevated exposure to OS is thought to play an important role in many diseases, including AMD. The RPE are exposed to chronically elevated levels of OS due to exposure to multiple endogenous (lipofuscin-sensitized photo-oxidation, digestion of outer segments, etc.) and exogenous (UV light exposure, cigarette smoking, etc.) stressors. This elevated ROS levels can be neutralized by endogenous antioxidant enzymes or by consumption of dietary vitamins. Currently, antioxidant-containing multivitamin supplements are taken as preventive agents for AMD because of their known antioxidant and anti-inflammatory activity and because they have been shown 
to be clinically effective for more advanced stages of AMD [5] [6] [54]. Identification of vitamins and nutraceuticals that are effective at limiting OS in the retina may increase treatment options for diseases, like AMD.

We have previously shown that OS-induced AP1 gene expression can be used as a quantitative biomarker of OS in a lab-based assay to examine the efficacy of vitamin treatment. AP1 transcription factors (FOSB, CFOS, and ATF3) are early responders whose mRNA and protein levels are dose- and time-dependently increased 1 - 8 $\mathrm{h}$ after exposure to OS [46]. The expression of other AP1 transcription factors (i.e. JUNB and CJUN) were also modestly activated by OS exposure, but were excluded from our biomarker assay because the small quantitative effect would make it difficult to identify modulation of this OS-induced response [46]. Pretreatment with 200 $\mu \mathrm{M}$ vitamin $\mathrm{C}$ was shown to modulate OS-induced AP1 expression, while a lower "sub-therapeutic" dose of vitamin C $(100 \mu \mathrm{M})$ alone had a small though statistically insignificant protective effect [47]. Here we tested the efficacy of combined vitamin A and C exposure to modulate OS-induced AP1 gene expression in RPE cells. We observed an additive effect of vitamin A and C on FOSB expression at $4 \mathrm{~h}$ OS, a potential protective effect of $100 \mu \mathrm{M}$ vitamin C and $15 \mu \mathrm{M}$ vitamin A on CFOS expression at $1 \mathrm{~h}$ OS, and a potential protective effect for 15 $\mu \mathrm{M}$ vitamin A only on ATF3 expression at $4 \mathrm{~h}$ OS. We did not detect a synergistic effect of vitamin $\mathrm{A}$ and $\mathrm{C}$ on AP1 expression, but the effect of combined vitamin C plus A pretreatment was greater than with "sub-therapeutic" levels of vitamin C $(100 \mu \mathrm{M})$ alone [47]. Thus, combined treatment with lower levels of vitamins can enhance the protective effect of exposure to a higher dose using a single vitamin. Some vitamins are known to interact with each other and analysis of their combined effect on OS-mediated AP1 expression warrants further investigation. For example, vitamin $\mathrm{C}$ can reduce vitamin $\mathrm{E}$ radicals to restore vitamin $\mathrm{E}$ antioxidant function [24] [29] [55]-[57]. Identification of vitamin combinations that are efficacious in multivitamin formulations at lower concentrations may limit adverse side effects and allow more vitamins to be physically packaged into an oral formulation.

We also examined the effect of vitamin E on OS-induced AP1 expression. Vitamin E pretreatment reduced OS-induced AP1 expression at a dose of $\geq 2.5 \mu \mathrm{M}$ (Figure 1), which was not further reduced by pretreatment with higher levels of vitamin $\mathrm{E}$. The vitamin $\mathrm{E}$ levels tested were within the physiological rage of vitamin $\mathrm{E}$ in vivo (the normal vitamin $\mathrm{E}$ range in human serum is $\sim 30 \mu \mathrm{mol} / \mathrm{L}$ ) [58]. Vitamin $\mathrm{E}$ is an essential dietary substance for human health, and vitamin $\mathrm{E}$ deficiency in humans is associated with neurological and retinal abnormalities and other systemic manifestations. Vitamin E encompasses a group of eight fat-soluble compounds, of which $\alpha$-tocopherol is the important biological molecule because it is selectively absorbed by the liver, through its interaction with $\alpha$-tocopherol transfer protein (TTPA) [59]-[62]. Maintenance of vitamin E levels in the eye is important for preservation of normal retinal morphology and visual function. Vitamin E deficiency, caused by a diet lacking vitamin $\mathrm{E}$ or by mutations of the TTPA gene, can cause retinitis pigmentosa [63]-[66], degenerative damage to the mouse retina [67], disorganized rod outer segments in rats and the accumulation of large lipofuscin granules leading to apoptosis in RPE cells [68] [69]. This effect also can be exacerbated by a diet which is also low in vitamin A [69]. OS has been shown to increases TTPA expression, thus high levels of OS in RPE cells may also increase TTPA expression and retinal vitamin E levels [59] [70] [71]. In addition to its radical-scavenging properties, vitamin E also alters gene expression, inhibits cell growth and inhibits PKC activity, which may enable vitamin $\mathrm{E}$ to indirectly regulate vascular endothelial growth factor-induced blood-retinal barrier dysfunction and neovascular AMD [72]-[75]. Vitamin E treatment, alone and in combination with vitamin C, has been shown to protect some cells, including ARPE-19 cells, from OS-induced cell damage, at least in part through reduced expression of AP1 and activation of Nrf2 and the phase II antioxidant enzymes [27] [49] [76]-[81]. Thus our results are consistent with published effects of vitamin E on OS-induced AP1 expression. While we only tested AP1 responses, it is possible that vitamin E also protects the RPE through activation of other transcription factors, like NRF2 and increased expression of antioxidant enzymes [82] [83].

Vitamin A consists of a group of fat-soluble compounds, whose functional biological metabolites plays an essential role in the immunity, embryogenesis, cellular growth and metabolism, visual cycle and retinal function [84]. Vitamin A metabolites can alter the cellular redox status through its antioxidant activities and by activating nuclear retinoic acid receptors and retinoid " $\mathrm{X}$ " receptors which can antagonize AP1-mediated gene expression, and can regulate expression of genes that protect the cell from apoptosis and alter the cellular redox status [12] [85]-[88]. Vitamin A is also able to repress both matrix metalloproteinase activity [89] [90] and VEGF expression [91], both of which are correlated with the development of neovascular AMD. Tissue levels of vitamin A metabolites are maintained by cyclical reactions, which recycle vitamin A and prevent its depletion. Importantly, vitamin A deficiency or genetic mutations that impair vitamin A renewal cause retinal degeneration and vision 
loss in mouse models [92]. However, vitamin A toxicity may occur because the absorption of preformed vitamin A does not have a mechanism to control its levels and prevent toxicity [93] [94]. Thus a lower vitamin A dose may reduce cellular toxicity while preserving therapeutic efficacy.

\section{Conclusion}

Using AP1 transcription as an in vitro biomarker for OS in the RPE, we have shown that there are optimal levels of vitamin supplementation ( $\geq 2.5 \mu \mathrm{M}$ Vitamin E or $100 \mu \mathrm{M}$ vitamin C plus $15 \mu \mathrm{M}$ vitamin A) that protect the RPE from OS-induced activation AP1 gene expression in vitro. Additionally, combined treatment with lower doses of vitamin $\mathrm{A}(15 \mu \mathrm{M})$ plus vitamin $\mathrm{C}(100 \mu \mathrm{M})$ can enhance the effectiveness modulating OS responses over higher doses of single vitamins alone in vitro. These results suggest that optimal antioxidant nutrition may be best achieved by a balance of low levels of dietary nutrients that enhances the protective effect of each other, not through the large dose, reductionist strategies currently employed by the nutritional supplement industry and consumed by the public. We propose that biomarkers, like the AP1 transcription factors, can be used to define molecular responses to new drugs and nutritional antioxidants that mitigate OS in the RPE. Laboratory-based assays can allow exploration of the therapeutic efficacy of known and new antioxidants, optimize dosing associated with beneficial biological responses and explore potential inhibitory interactions between compounds in vitro, prior to testing in expensive clinical trials, which may lead to the discovery of additional and more effective treatments for diseases like AMD.

\section{Acknowledgements}

J.Y. and C.S.W. were responsible for performance and analysis of in vitro studies, manuscript co-authorship; F.T. and Q.T.T. designed the statistical methods and statistical analyses; E.C. principal investigator, conceived studies, data analyses, manuscript co-authorship; J.C.L. co-investigator, data analysis, manuscript co-authorship. All Authors have read and approved the manuscript. The authors would like to acknowledge the contribution Ms. Weihong Huo for her technical assistance in performing the studies presented. These studies were supported in part by an unrestricted UTHSC departmental grant from Research to Prevent Blindness, New York, NY, the Plough Foundation, Memphis, TN, The Lions of Arkansas Foundation Inc., Alcon Research Inc., Ft. Worth, TX, and the UTHSC Hamilton Eye Institute NEI Core Grant for Vision Research (P30 EY013080).

\section{References}

[1] Halliwell, B., Hu, M.L., Louie, S., Duvall, T.R., Tarkington, B.K., Motchnik, P. and Cross, C.E. (1992) Interaction of Nitrogen Dioxide with Human Plasma. Antioxidant Depletion and Oxidative Damage. FEBS Letters, 313, 62-66. http://dx.doi.org/10.1016/0014-5793(92)81185-O

[2] Winkler, B.S., Boulton, M.E., Gottsch, J.D. and Sternberg, P. (1999) Oxidative Damage and Age-Related Macular Degeneration. Molecular Vision, 5, 32-59.

[3] Jarrett, S.G. and Boulton, M.E. (2012) Consequences of Oxidative Stress in Age-Related Macular Degeneration. Molecular Aspects of Medicine, 33, 399-417. http://dx.doi.org/10.1016/j.mam.2012.03.009

[4] Tokarz, P., Kaarniranta, K. and Blasiak, J. (2013) Role of Antioxidant Enzymes and Small Molecular Weight Antioxidants in the Pathogenes Is of Age-Related Macular Degeneration (AMD). Biogerontology, 14, 461-482. http://dx.doi.org/10.1007/s10522-013-9463-2

[5] Age-Related Eye Disease Study Research Group (2001) A Randomized, Placebo-Controlled, Clinical Trial of HighDose Supplementation with Vitamins C and E, Beta Carotene, and Zinc for Age-Related Macular Degeneration and Vision Loss: AREDS Report No. 8. Archives of Ophthalmology, 119, 1417-1436. http://dx.doi.org/10.1001/archopht.119.10.1417

[6] Age-Related Eye Disease Study Research Group, SanGiovanni, J.P., Chew, E.Y., Clemons, T.E., Ferris 3rd, F.L., Gensler, G., Lindblad, A.S., Milton, R.C., Seddon, J.M. and Sperduto, R.D. (2007) The Relationship of Dietary Carotenoid and Vitamin A, E, and C Intake with Age-Related Macular Degeneration in a Case-Control Study: AREDS Report No. 22. Archives of Ophthalmology, 125, 1225-1232.

[7] Amann, P.M., Eichmuller, S.B., Schmidt, J. and Bazhin, A.V. (2011) Regulation of Gene Expression by Retinoids. Current Medicinal Chemistry, 18, 1405-1412. http://dx.doi.org/10.2174/092986711795029618

[8] Dawson, M.I. and Xia, Z. (2012) The Retinoid X Receptors and Their Ligands. Biochimica et Biophysica Acta, 1821, 21-56. http://dx.doi.org/10.1016/j.bbalip.2011.09.014 
[9] Salbert, G., Fanjul, A., Piedrafita, F.J., Lu, X.P., Kim, S.J., Tran, P. and Pfahl, M. (1993) Retinoic Acid Receptors and Retinoid X Receptor-Alpha Down-Regulate the Transforming Growth Factor-Beta 1 Promoter by Antagonizing AP-1 Activity. Molecular Endocrinology, 7, 1347-1356.

[10] Pfahl, M. and Piedrafita, F.J. (2003) Retinoid Targets for Apoptosis Induction. Oncogene, 22, 9058-9062. http://dx.doi.org/10.1038/sj.onc.1207109

[11] Abate, C., Patel, L., Rauscher 3rd, F.J. and Curran, T. (1990) Redox Regulation of Fos and Jun DNA-Binding Activity in Vitro. Science, 249, 1157-1161. http://dx.doi.org/10.1126/science.2118682

[12] Benkoussa, M., Brand, C., Delmotte, M.H., Formstecher, P. and Lefebvre, P. (2002) Retinoic Acid Receptors Inhibit AP1 Activation by Regulating Extracellular Signal-Regulated Kinase and CBP Recruitment to an AP1-Responsive Promoter. Molecular and Cellular Biology, 22, 4522-4534. http://dx.doi.org/10.1128/MCB.22.13.4522-4534.2002

[13] Froeschle, A., Carnac, G., Alric, S., Montarras, D., Pinset, C., Rochette-Egly, C. and Bonnieu, A. (1996) RXR Alpha Is Essential for Mediating the All-Trans Retinoic Acid-Induced Growth Arrest of C2 Myogenic Cells. Oncogene, 12, 411-421.

[14] Ding, Y., Qiao, A., Wang, Z., Goodwin, J.S., Lee, E.S., Block, M.L., Allsbrook, M., McDonald, M.P. and Fan, G.H. (2008) Retinoic Acid Attenuates Beta-Amyloid Deposition and Rescues Memory Deficits in an Alzheimer's Disease Transgenic Mouse Model. The Journal of Neuroscience, 28, 11622-11634. http://dx.doi.org/10.1523/JNEUROSCI.3153-08.2008

[15] Maden, M. (2007) Retinoic Acid in the Development, Regeneration and Maintenance of the Nervous System. Nature Reviews Neuroscience, 8, 755-765. http://dx.doi.org/10.1038/nrn2212

[16] Malaspina, A. and Michael-Titus, A.T. (2008) Is the Modulation of Retinoid and Retinoid-Associated Signaling a Future Therapeutic Strategy in Neurological Trauma and Neurodegeneration? Journal of Neurochemistry, 104, 584-595.

[17] Chang, H.J., Park, J.S., Lee, E.K., Kim, M.H., Baek, M.K., Kim, H.R., Jeong, H.G., Choi, S.Y. and Jung, Y.D. (2009) Ascorbic Acid Suppresses the 2,3,7,8-Tetrachloridibenxo-p-Dioxin (TCDD)-Induced CYP1A1 Expression in Human HepG2 Cells. Toxicology in Vitro, 23, 622-626. http://dx.doi.org/10.1016/j.tiv.2009.02.008

[18] Duarte, T.L. and Lunec, J. (2005) Review: When Is an Antioxidant Not an Antioxidant? A Review of Novel Actions and Reactions of Vitamin C. Free Radical Research, 39, 671-686. http://dx.doi.org/10.1080/10715760500104025

[19] May, J.M. (1999) Is Ascorbic Acid an Antioxidant for the Plasma Membrane? The FASEB Journal, 13, 995-1006.

[20] Lane, D.J. and Lawen, A. (2009) Ascorbate and Plasma Membrane Electron Transport—Enzymes vs Efflux. Free Radical Biology and Medicine, 47, 485-495. http://dx.doi.org/10.1016/j.freeradbiomed.2009.06.003

[21] Thompson, D.A. and Gal, A. (2003) Vitamin A Metabolism in the Retinal Pigment Epithelium: Genes, Mutations, and Diseases. Progress in Retinal and Eye Research, 22, 683-703. http://dx.doi.org/10.1016/S1350-9462(03)00051-X

[22] Azzi, A. (2004) The Role of Alpha-Tocopherol in Preventing Disease. European Journal of Nutrition, 43, I/18-25.

[23] Azzi, A., Ricciarelli, R. and Zingg, J.M. (2002) Non-Antioxidant Molecular Functions of Alpha-Tocopherol (Vitamin E). FEBS Letters, 519, 8-10. http://dx.doi.org/10.1016/S0014-5793(02)02706-0

[24] Burton, G.W. and Ingold, K.U. (1989) Vitamin E as an in Vitro and in Vivo Antioxidant. Annals of the New York Academy of Sciences, 570, 7-22. http://dx.doi.org/10.1111/j.1749-6632.1989.tb14904.x

[25] Traber, M.G. (2007) Vitamin E Regulatory Mechanisms. Annual Review of Nutrition, 27, 347-362. http://dx.doi.org/10.1146/annurev.nutr.27.061406.093819

[26] Yamauchi, J., Iwamoto, T., Kida, S., Masushige, S., Yamada, K. and Esashi, T. (2001) Tocopherol-Associated Protein Is a Ligand-Dependent Transcriptional Activator. Biochemical and Biophysical Research Communications, 285, 295299. http://dx.doi.org/10.1006/bbrc.2001.5162

[27] Darwiche, N., Bazzi, H., El-Touni, L., Abou-Lteif, G., Doueiri, R., Hatoum, A., Maalouf, S. and Gali-Muhtasib, H. (2005) Regulation of Ultraviolet B Radiation-Mediated Activation of AP1 Signaling by Retinoids in Primary Keratinocytes. Radiation Research, 163, 296-306. http://dx.doi.org/10.1667/RR3318

[28] Kagan, D.B., Liu, H. and Hutnik, C.M. (2012) Efficacy of Various Antioxidants in the Protection of the Retinal Pigment Epithelium from Oxidative Stress. Clinical Ophthalmology, 6, 1471-1476.

[29] Rozanowska, M., Bakker, L., Boulton, M.E. and Rozanowski, B. (2012) Concentration Dependence of Vitamin C in Combinations with Vitamin E and Zeaxanthin on Light-Induced Toxicity to Retinal Pigment Epithelial Cells. Photochemistry and Photobiology, 88, 1408-1417. http://dx.doi.org/10.1111/j.1751-1097.2012.01228.x

[30] Loke, W.M., Proudfoot, J.M., McKinley, A.J. and Croft, K.D. (2006) Augmentation of Monocyte Intracellular Ascorbate in Vitro Protects Cells from Oxidative Damage and Inflammatory Responses. Biochemical and Biophysical Research Communications, 345, 1039-1043. http://dx.doi.org/10.1016/j.bbrc.2006.04.174

[31] Chen, J.Y., Penco, S., Ostrowski, J., Balaguer, P., Pons, M Starrett, J.E., Reczek, P., Chambon, P. and Gronemeyer, H. (2006) RAR-Specific Agonist/Antagonists Which Dissociate Transactivation and AP1 Transrepression Inhibit Anchorage-Independent Cell Proliferation. The EMBO Journal, 14, 1187-1197. 
[32] Dedieu, S. and Lefebvre, P. (2006) Retinoids Interfere with the AP1 Signalling Pathway in Human Breast Cancer Cells. Cellular Signalling, 18, 889-898. http://dx.doi.org/10.1016/j.cellsig.2005.08.001

[33] Amstad, P.A., Krupitza, G. and Cerutti, P.A. (1992) Mechanism of c-Fos induction by Active Oxygen. Cancer Research, 52, 3952-3960.

[34] Devary, Y., Gottlieb, R.A., Lau, L.F. and Karin, M. (1991) Rapid and Preferential Activation of the c-Jun Gene during the Mammalian UV Response. Molecular and Cellular Biology, 11, 2804-2811. http://dx.doi.org/10.1128/MCB.11.5.2804

[35] Geller, S.F. and Stone, J. (2003) Quantitative PCR Analysis of FosB mRNA Expression after Short Duration Oxygen and Light Stress. Advances in Experimental Medicine and Biology, 533, 249-257. http://dx.doi.org/10.1007/978-1-4615-0067-4_31

[36] Karin, M. (1995) The Regulation of AP-1 Activity by Mitogen-Activated Protein Kinases. The Journal of Biological Chemistry, 270, 16483-16486. http://dx.doi.org/10.1074/jbc.270.28.16483

[37] Morris, B.J. (1995) Stimulation of Immediate Early Gene Expression in Striatal Neurons by Nitric Oxide. The Journal of Biological Chemistry, 270, 24740-24744.

[38] Cavigelli, M., Li, W.W., Lin, A., Su, B., Yoshioka, K. and Karin, M. (1996) The Tumor Promoter Arsenite Stimulates AP-1 Activity by Inhibiting a JNK Phosphatase. The EMBO Journal, 15, 6269-6279.

[39] Karin, M. and Shaulian, E. (2001) AP-1: Linking Hydrogen Peroxide and Oxidative Stress to the Control of Cell Proliferation and Death. IUBMB Life, 52, 17-24. http://dx.doi.org/10.1080/15216540252774711

[40] Lallemand, D., Spyrou, G., Yaniv, M. and Pfarr, C.M. (1997) Variations in Jun and Fos Protein Expression and AP-1 Activity in Cycling, Resting and Stimulated Fibroblasts. Oncogene, 14, 819-830. http://dx.doi.org/10.1038/sj.onc.1200901

[41] Morgan, J.I. and Curran, T. (1991) Stimulus-Transcription Coupling in the Nervous System: Involvement of the Inducible Proto-Oncogenes Fos and Jun. Annual Review of Neuroscience, 14, 421-451. http://dx.doi.org/10.1146/annurev.ne.14.030191.002225

[42] Xanthoudakis, S. and Curran, T. (1992) Identification and Characterization of Ref-1, a Nuclear Protein That Facilitates AP-1 DNA-Binding Activity. The EMBO Journal, 11, 653-665.

[43] Zhou, L.Z., Johnson, A.P. and Rando, T.A. (2001) NF Kappa B and AP-1 Mediate Transcriptional Responses to Oxidative Stress in Skeletal Muscle Cells. Free Radical Biology \& Medicine, 31, 1405-1416. http://dx.doi.org/10.1016/S0891-5849(01)00719-5

[44] Shaulian, E. and Karin, M. (2002) AP-1 as a Regulator of Cell Life and Death. Nature Cell Biology, 4, E131-E136. http://dx.doi.org/10.1038/ncb0502-e131

[45] Shaulian, E. and Karin, M. (2001) AP-1 in Cell Proliferation and Survival. Oncogene, 20, 2390-2400. http://dx.doi.org/10.1038/sj.onc.1204383

[46] Chaum, E., Yin, J., Yang, H., Thomas, F. and Lang, J.C. (2009) Quantitative AP-1 Gene Regulation by Oxidative Stress in the Human Retinal Pigment Epithelium. Journal of Cellular Biochemistry, 108, 1280-1291. http://dx.doi.org/10.1002/jcb.22358

[47] Yin, J., Thomas, F., Lang, J.C. and Chaum, E. (2011) Modulation of Oxidative Stress Responses in the Human Retinal Pigment Epithelium Following Treatment with Vitamin C. Journal of Cellular Physiology, 226, 2025-2032. http://dx.doi.org/10.1002/jcp.22532

[48] Yang, H., Yang, X., Lang, J.C. and Chaum, E. (2006) Tissue Culture Methods Can Strongly Induce Immediate Early Gene Expression in Retinal Pigment Epithelial Cells. Journal of Cellular Biochemistry, 98, 1560-1569. http://dx.doi.org/10.1002/jcb.20877

[49] Gao, S., Qin, T., Liu, Z., Caceres, M.A., Ronchi, C.F., Chen, C.Y., Yeum, K.J., Taylor, A., Blumberg, J.B., Liu, Y. and Shang, F. (2011) Lutein and Zeaxanthin Supplementation Reduces $\mathrm{H}_{2} \mathrm{O}_{2}$-Induced Oxidative Damage in Human Lens Epithelial Cells. Molecular Vision, 17, 3180-3190.

[50] Hothorn, T., Bretz, F. and Westfall, P. (2008) Simultaneous Inference in General Parametric Models. Biometrical Journal, 50, 346-363. http://dx.doi.org/10.1002/bimj.200810425

[51] Van Belle, G., Fisher, L.D., Heagerty, P.J. and Lumley, T. (2004) Biostatistics: A Methodology for the Health Sciences. Wiley, Hoboken. http://dx.doi.org/10.1002/0471602396

[52] Kunter, M., Nachtsheim, C., Neter, J. and Li, W. (2005) Applied Linear Statistical Models. McGraw-Hill/Irvin, Boston.

[53] Montgomery, D.C. (2001) Design and Analysis of Experiments. Wiley, Hoboken.

[54] Chew, E.Y., Clemons, T.E., Agron, E., Sperduto, R.D., Sangiovanni, J.P., Kurinij, N. and Davis, M.D., Age-Related Eye Disease Study Research Group (2013) Long-Term Effects of Vitamins C and E, Beta-Carotene, and Zinc on Age-Related Macular Degeneration: AREDS Report No. 35. Ophthalmology, 120, 1604.e4-1611.e4. 
[55] Kagan, V.E., Serbinova, E.A., Forte, T., Scita, G. and Packer, L. (1992) Recycling of Vitamin E in Human Low Density Lipoproteins. The Journal of Lipid Research, 33, 385-397.

[56] Niki, E. (1987) Interaction of Ascorbate and Alpha-Tocopherol. Annals of the New York Academy of Sciences, 498, 186-199. http://dx.doi.org/10.1111/j.1749-6632.1987.tb23761.x

[57] Niki, E., Saito, T., Kawakami, A. and Kamiya, Y. (1984) Inhibition of Oxidation of Methyl Linoleate in Solution by Vitamin E and Vitamin C. The Journal of Biological Chemistry, 259, 4177-4182.

[58] Ford, E.S., Schleicher, R.L., Mokdad, A.H., Ajani, U.A. and Liu, S. (2006) Distribution of Serum Concentrations of $\alpha$-Tocopherol and $\gamma$-Tocopherol in the US Population. The American Journal of Clinical Nutrition, 84, 375-383.

[59] Hosomi, A., Goto, K., Kondo, H., Iwatsubo, T., Yokota, T., Ogawa, M., Arita, M., Aoki, J., Arai, H. and Inoue K. (1998) Localization of Alpha-Tocopherol Transfer Protein in Rat Brain. Neuroscience Letters, 256, 159-162. http://dx.doi.org/10.1016/S0304-3940(98)00785-X

[60] Morley, S., Cecchini, M., Zhang, W., Virgulti, A., Noy, N., Atkinson, J. and Manor, D. (2008) Mechanisms of Ligand Transfer by the Hepatic Tocopherol Transfer Protein. The Journal of Biological Chemistry, 283, 17797-17804. http://dx.doi.org/10.1074/jbc.m800121200

[61] Shichiri, M., Takanezawa, Y., Rotzoll, D.E., Yoshida, Y., Kokubu, T., Ueda, K., Tamai, H. and Arai, H. (2010) ATP-Binding Cassette Transporter A1 Is Involved in Hepatic Alpha-Tocopherol Secretion. The Journal of Nutritional Biochemistry, 21, 451-456. http://dx.doi.org/10.1016/j.jnutbio.2009.02.002

[62] Thakur, V., Morley, S. and Manor, D. (2010) Hepatic Alpha-Tocopherol Transfer Protein: Ligand-Induced Protection from Proteasomal Degradation. Biochemistry, 49, 9339-9344. http://dx.doi.org/10.1021/bi100960b

[63] Ouahchi, K., Arita, M., Kayden, H., Hentati, F., Ben Hamida, M., Sokol, R., Arai, H., Inoue, K., Mandel, J.L. and Koenig, M. (1995) Ataxia with Isolated Vitamin E Deficiency Is Caused by Mutations in the Alpha-Tocopherol Transfer Protein. Nature Genetics, 9, 141-145. http://dx.doi.org/10.1038/ng0295-141

[64] Yokota, T., Igarashi, K., Uchihara, T., Jishage, K., Tomita, H., Inaba, A., Li, Y., Arita, M., Suzuki, H., Mizusawa, H. and Aria, H. (2001) Delayed-Onset Ataxia in Mice Lacking Alpha-Tocopherol Transfer Protein: Model for Neuronal Degeneration Caused by Chronic Oxidative Stress. Proceedings of the National Academy of Sciences of the United States of America, 98, 15185-15190. http://dx.doi.org/10.1073/pnas.261456098

[65] Yokota, T., Shiojiri, T., Gotoda, T. and Arai, H. (1996) Retinitis Pigmentosa and Ataxia Caused by a Mutation in the Gene for the Alpha-Tocopherol-Transfer Protein. The New England Journal of Medicine, 335, 1770-1771. http://dx.doi.org/10.1056/NEJM199612053352315

[66] Yokota, T., Uchihara, T., Kumagai, J., Shiojiri, T., Pang, J.J., Arita, M., Arai, H., Hayashi, M., Kiyosawa, M., Okeda, R. and Mizusawa, H. (2000) Postmortem Study of Ataxia with Retinitis Pigmentosa by Mutation of the Alpha-Tocopherol Transfer Protein Gene. Journal of Neurology, Neurosurgery \& Psychiatry, 68, 521-525. http://dx.doi.org/10.1136/jnnp.68.4.521

[67] Tanito, M., Yoshida, Y., Kaidzu, S., Chen, Z.H., Cynshi, O., Jishage, K., Niki, E. and Ohira, A. (2007) Acceleration of Age-Related Changes in the Retina in Alpha-Tocopherol Transfer Protein Null Mice Fed a Vitamin E-Deficient Diet. Investigative Ophthalmology \& Visual Science, 48, 396-404. http://dx.doi.org/10.1167/iovs.06-0872

[68] Robison Jr., W.G., Kuwabara, T. and Bieri, J.G. (1979) Vitamin E Deficiency and the Retina: Photoreceptor and Pigment Epithelial Changes. Investigative Ophthalmology \& Visual Science, 18, 683-690.

[69] Robison Jr., W.G., Kuwabara, T. and Bieri, J.G. (1980) Deficiencies of Vitamins E and A in the Rat. Retinal Damage and Lipofuscin Accumulation. Investigative Ophthalmology \& Visual Science, 19, 1030-1037.

[70] Etzl, R.P., Vrekoussis, T., Kuhn, C., Schulze, S., Poschl, J.M., Makrigiannakis, A., Jeschke, U. and Rotzoll, D.E. (2012) Oxidative Stress Stimulates Alpha-Tocopherol Transfer Protein in Human Trophoblast Tumor Cells BeWo. Journal of Perinatal Medicine, 40, 373-378. http://dx.doi.org/10.1515/jpm-2011-0307

[71] Ulatowski, L., Dreussi, C., Noy, N., Barnholtz-Sloan, J., Klein, E. and Manor, D. (2012) Expression of the AlphaTocopherol Transfer Protein Gene Is Regulated by Oxidative Stress and Common Single-Nucleotide Polymorphisms. Free Radical Biology \& Medicine, 53, 2318-2326. http://dx.doi.org/10.1016/j.freeradbiomed.2012.10.528

[72] Titchenell, P.M., Lin, C.M., Keil, J.M., Sundstrom, J.M., Smith, C.D. and Antonetti, D.A. (2012) Novel Atypical PKC Inhibitors Prevent Vascular Endothelial Growth Factor-Induced Blood-Retinal Barrier Dysfunction. Biochemical Journal, 446, 455-467. http://dx.doi.org/10.1042/BJ20111961

[73] Azzi, A., Breyer, I., Feher, M., Ricciarelli, R., Stocker, A., Zimmer, S. and Zingg, J. (2001) Nonantioxidant Functions of Alpha-Tocopherol in Smooth Muscle Cells. Journal of Nutrition, 131, 378S-381S.

[74] Ricciarelli, R., Tasinato, A., Clement, S., Ozer, N.K., Boscoboinik, D. and Azzi, A. (1998) Alpha-Tocopherol Specifically Inactivates Cellular Protein Kinase C Alpha by Changing Its Phosphorylation State. Biochemical Journal, 334, 243-249. http://dx.doi.org/10.1042/bj3340243

[75] Azzi, A., Boscoboinik, D., Clement, S., Ozer, N., Ricciarelli, R. and Stocker, A. (1999) Vitamin E Mediated Response 
of Smooth Muscle Cell to Oxidant Stress. Diabetes Research and Clinical Practice, 45, 191-198. http://dx.doi.org/10.1016/S0168-8227(99)00049-2

[76] Feng, Z., Liu, Z., Li, X., Jia, H., Sun, L., Tian, C., Jia, L. and Liu, J. (2010) Alpha-Tocopherol Is an Effective Phase II Enzyme Inducer: Protective Effects on Acrolein-Induced Oxidative Stress and Mitochondrial Dysfunction in Human Retinal Pigment Epithelial Cells. The Journal of Nutritional Biochemistry, 21, 1222-1231. http://dx.doi.org/10.1016/j.jnutbio.2009.10.010

[77] Niture, S.K., Khatri, R. and Jaiswal, A.K. (2013) Regulation of Nrf2-An Update. Free Radical Biology \& Medicine, 66, 36-44. http://dx.doi.org/10.1016/j.freeradbiomed.2013.02.008

[78] Maziere, C., Conte, M.A., Degonville, J., Ali, D. and Maziere, J.C. (1999) Cellular Enrichment with Polyunsaturated Fatty Acids Induces an Oxidative Stress And activates the Transcription Factors AP1 and NFkappaB. Biochemical and Biophysical Research Communications, 265, 116-122. http://dx.doi.org/10.1006/bbrc.1999.1644

[79] Catani, M.V., Rossi, A., Costanzo, A., Sabatini, S., Levrero, M., Melino, G. and Avigliano, L. (2001) Induction of Gene Expression via Activator Protein-1 in the Ascorbate Protection against UV-Induced Damage. Biochemical Journal, 356, 77-85. http://dx.doi.org/10.1042/bj3560077

[80] Hoshikawa, Y., Kanki, K., Ashla, A.A., Arakaki, Y., Azumi, J., Yasui, T., Tezuka, Y., Matsumi, Y., Tsuchiya, H., Kurimasa, A., Hisatome, I., Hirano, T., Fujimoto, J., Kagechika, H., Shomori, K., Ito, H. and Shiota, G. (2011) c-Jun N-Terminal Kinase Activation by Oxidative Stress Suppresses Retinoid Signaling through Proteasomal Degradation of Retinoic Acid Receptor Alpha Protein in Hepatic Cells. Cancer Science, 102, 934-941. http://dx.doi.org/10.1111/j.1349-7006.2011.01889.x

[81] Mehta, K. (2003) Retinoids as Regulators of Gene Transcription. Journal of Biological Regulators \& Homeostatic Agents, 17, 1-12.

[82] Rohrdanz, E. and Kahl, R. (1998) Alterations of Antioxidant Enzyme Expression in Response to Hydrogen Peroxide. Free Radical Biology \& Medicine, 24, 27-38. http://dx.doi.org/10.1016/S0891-5849(97)00159-7

[83] Tate Jr., D.J., Miceli, M.V. and Newsome, D.A. (1995) Phagocytosis and $\mathrm{H}_{2} \mathrm{O}_{2}$ Induce Catalase and Metallothionein Gene Expression in Human Retinal Pigment Epithelial Cells. Investigative Ophthalmology \& Visual Science, 36, 12711279.

[84] Palczewski, K. (2010) Retinoids for Treatment of Retinal Diseases. Trends in Pharmacological Sciences, 31, $284-295$. http://dx.doi.org/10.1016/j.tips.2010.03.001

[85] Sharoni, Y., Danilenko, M., Dubi, N., Ben-Dor, A. and Levy, J. (2004) Carotenoids and Transcription. Archives of Biochemistry and Biophysics, 430, 89-96. http://dx.doi.org/10.1016/j.abb.2004.03.009

[86] DiSepio, D., Sutter, M., Johnson, A.T., Chandraratna, R.A. and Nagpal, S. (1999) Identification of the AP1-Antagonism Domain of Retinoic Acid Receptors. Molecular Cell Biology Research Communications, 1, 7-13. http://dx.doi.org/10.1006/mcbr.1999.0101

[87] Schule, R., Rangarajan, P., Yang, N., Kliewer, S., Ransone, L.J., Bolado, J., Verma, I.M. and Evans, R.M. (1991) Retinoic Acid Is a Negative Regulator of AP-1-Responsive Genes. Proceedings of the National Academy of Sciences of the United States of America, 88, 6092-6096. http://dx.doi.org/10.1073/pnas.88.14.6092

[88] Zhou, X.F., Shen, X.Q. and Shemshedini, L. (1999) Ligand-Activated Retinoic Acid Receptor Inhibits AP-1 Transactivation by Disrupting c-Jun/c-Fos Dimerization. Molecular Endocrinology, 13, 276-285. http://dx.doi.org/10.1210/mend.13.2.0237

[89] Du, Y.H., Hirooka, K., Miyamoto, O., Bao, Y.Q., Zhang, B, An, J.B. and Ma, J.X. (2013) Retinoic Acid Suppresses the Adhesion and Migration of Human Retinal Pigment Epithelial Cells. Experimental Eye Research, 109, 22-30. http://dx.doi.org/10.1016/j.exer.2013.01.006

[90] Dutta, A., Sen, T. and Chatterjee, A. (2010) All-Trans Retinoic Acid (ATRA) Downregulates MMP-9 by Modulating Its Regulatory Molecules. Cell Adhesion \& Migration, 4, 409-418. http://dx.doi.org/10.4161/cam.4.3.11682

[91] Diaz, B.V., Lenoir, M.C., Ladoux, A., Frelin, C., Demarchez, M. and Michel, S. (2000) Regulation of Vascular Endothelial Growth Factor Expression in Human Keratinocytes by Retinoids. The Journal of Biological Chemistry, 275, 642-650. http://dx.doi.org/10.1074/jbc.275.1.642

[92] Perusek, L. and Maeda, T. (2013) Vitamin A Derivatives as Treatment Options for Retinal Degenerative Diseases. Nutrients, 5, 2646-2666. http://dx.doi.org/10.3390/nu5072646

[93] Harrison, E.H. (2012) Mechanisms Involved in the Intestinal Absorption of Dietary Vitamin A and Provitamin A Carotenoids. Biochimica et Biophysica Acta (BBA)-Molecular and Cell Biology of Lipids, 1821, 70-77. http://dx.doi.org/10.1016/j.bbalip.2011.06.002

[94] von Lintig, J. (2012) Provitamin A Metabolism and Functions in Mammalian Biology. The American Journal of Clinical Nutrition, 96, 1234S-1244S. http://dx.doi.org/10.3945/ajcn.112.034629 